\title{
Customer Touchpoint Management
}

\author{
Literaturhinweise zusammengestellt von Dipl.-Kfm. Jochen Binder
}

\section{Bücher}

Algesheimer, R. (2004)

Brand Communities: Begriff, Grundmodell und Implikationen, Wiesbaden.

Belz, Ch./Schögel, M./Arndt, O./Walter, V. (2008)

Interaktives Marketing - Neue Wege zum Dialog mit Kunden, Wiesbaden.

Belz, Ch./Schögel, M./Tomczak, T. (2007): Innovation driven Marketing: Vom Trend zur innovativen Marketinglösung, Wiesbaden.

Bruhn, M./Ahlers, G. M. (2007)

Customer Touch Points - Aufgaben und Vorgehensweise einer Multi-Channel-Communication, in: Wirtz, B. W. (Hrsg.): Handbuch Multi-Channel-Marketing, Wiesbaden, S. 393-426.

Kaul, H./Steinmann, C. (2008)

Community Marketing - Wie Unternehmen in sozialen Netzwerken Werte schaffen, Stuttgart.

Mahrdt, N. (2009)

Cross Media, Wiesbaden.

Reinecke, S./Rudolf-Sipötz, E./Wiemann, E. (1998)

Total Customer Care: Kundenorientierung auf dem Prüfstand, Wien.

Rutschmann, M. (2008)

Einzelhandel: Optionen des neuen Dialogs für den Einzelhandel, St. Gallen.

\section{Rutschmann, M. (2005)}

Kaufprozesse von Konsumenten erkennen und lenken - Mehr Marktanteil mit neuem Marketing, St. Gallen.

Schmitt, B. H. (2003)

Customer Experience Management, New Jersey.

\section{Schwarz, T. (2007)}

Leitfaden Online Marketing, Waghäusel.

Scott, D. M. (2007)

The New Rules of Marketing \& PR - How to use News Releases, Blogs, Podcasting, Viral Marketing \& Online Media to reach Buyers directly, Hoboken.
Tomczak, T./Belz, Ch./Schögel, M./Birkhofer, B. (1999)

Alternative Vertriebswege - neue Wege zum Kunden, St. Gallen.

Zanetti, D. (2005)

Kundenverblüffung - Kreative Tipps, wie Sie Ihre Kunden nachhaltig an sich binden, Frankfurt/Main.

\section{Artikel | Zeitschriften}

Cassab, H./MacLachlan, D. L. (2009)

A Consumer-based View of Multi-Channel Service, in: Journal of Service Management, 20, 1, S. 52-75.

Hogan, S./Almquist, E./Glynn, S. E. (2005) Brand Building: Finding the Touchpoints that count, in: Journal of Business Strategy, 26, 2, S. 11-18.

Hughes, T. (2005)

New Channels/Old Channels - Customer Management and Multi-Channels, in: European Journal of Marketing, 40, 1/2, S. 113-129.

Jindal, R. P./Reinartz, W./Krafft, M./Hoyer, W. D. (2007)

Determinants of the Variety of Routes to Market, in: International Journal of Research in Marketing, 24, 1, S. 17-29.

Krell, E. (2005)

The 6 most overlooked Customer Touch Points, in: The CRM Magazine, 9, 1, S. 40-43.

Mauch, W. (1990)

Bessere Kundenkontakte dank Sales Cycle, in: Thexis, 1/1990, S. 15-18.

McKenzie, K. E./Royne, M. B. (2010)

Defining and Understanding Communications Planning - A Current Assessment and an Exploratory Study, in: Journal of Promotion Management, 15, 3, S. 41-356.

Neslin, S. A./Shankar, V. (2009)

Key Issues in Mulitchannel Customer Management: Current Knowledge and Future Direction, in: Journal of Interactive Marketing, 23, 1, S. 70-81.
Payne, A./Frow, P. (2004)

The Role of Multichannel Integration in Customer Relationship Management, in: Industrial Marketing Management, 33, 6, S. 527-538.

Puccinelli, N. M./Goodstein, R. C./Grewal, D./Price, R./Raghubir, P./Stewart, D. (2009) Customer Experience Management in Retailing: Understanding the Buying Process, in: Journal of Retailing, 85, 1, S. 15-30.

Schögel, M. (2009)

Interaktives Marketing und neue Medien Kunden und Communities treiben die Inhalte, in: Marke 41, 2/2009, S. 14-19.

Schögel, M./Schulten, M./Herhausen, D. (2009)

Kunden erfolgreich dirigieren, in: Harvard Business Manager, 9/2009, S. 50-56.

Urban, G. L. (2005)

Customer Advocacy: A New Era in Marketing? in: Journal of Public Policy \& Marketing, 24, 1, S. 155-159.

Verhoef, P. C./Lemon, K. N./Parasuraman, A./Roggeveen, A./Tsiros, M./Schlesinger, L. A. (2009)

Customer Experience Creation: Determinants, Dynamics and Management Strategies, in: Journal of Retailing, 85, 1, S. 31-40.

Verhoef, P. C./Neslin, S. A./Vroomen, B. (2007) Multichannel Customer Management: Understanding the Research-Shopper Phenomenon, in: International Journal of Research in Marketing, 24, 2, S. 129-148.

Wilson, H./Hobbs, M./Dolder, C./McDonald, M. (2004)

Optimizing Multiple Channels, in: Interactive Marketing, 5, 3, S. 252-268. 